\title{
Reference evapotranspiration for Londrina, Paraná, Brazil: performance of different estimation methods
}

\section{Evapotranspiração de referência para Londrina, Paraná: desempenho de diferentes métodos de estimativa}

\author{
Rodrigo Dlugosz da Silva ${ }^{1 *}$; Marcelo Augusto de Aguiar e Silva ${ }^{2}$; Marcelo \\ Giovanetti Canteri²; Juliandra Rodrigues Rosisca ${ }^{3}$; Nilson Aparecido Vieira Junior ${ }^{4}$
}

\begin{abstract}
Aiming at assessing the performance of alternative methods to Penman-Monteith FAO56 for estimating the reference evapotranspiration (ETo) for Londrina, Paraná, Brazil, the methods temperature radiation, Hicks-Hess, Hargreaves-Samani (1982), Turc, Priestley-Taylor, Tanner-Pelton, Jensen-Haise, Makkink, modified Hargreaves, Stephens-Stewart, Abtew, global radiation, Ivanov, Lungeon, Hargreaves-Samani (1985), Benavides-Lopez, original Penman, Linacre, Blaney-Morin, Romanenko, Hargreaves (1974), McCloud, Camargo, Hamon, Kharrufa, McGuiness-Bordne, and Blaney-Criddle were compared to that standard method recommended by FAO. The estimations were correlated by linear regression and assessed by using the Person's correlation coefficient (r), concordance index (d), and performance index (c) using a set of meteorological data of approximately 40 years. The methods modified Hargreaves, Stephens-Stewart, Abtew, global radiation, Ivanov, Lungeon, Hargreaves-Samani (1985), BenavidesLopez, original Penman, and Linacre should be avoided, as they did not present excellent results. The methods McCloud, Camargo, Hamon, Kharrufa, McGuinness-Bordne, Blaney-Criddle, Hargreaves (1974), Romanenko, and Blaney-Morin were classified as very bad, not being recommended. In contrast, the methods temperature radiation, Hicks-Hess, Hargreaves-Samani (1982), Turc, PriestleyTaylor, Tenner-Pelton, Jensen-Haise, and Makkink presented excellent performance indices and can be applied in the study region.
\end{abstract}

Key words: Potential evapotranspiration. Calculation models. Decision-making.

\section{Resumo}

Com objetivo de avaliar o desempenho de métodos alternativos ao Penmam-Monteith-FAO56 para a estimativa da evapotranspiração de referência (ETo) para a cidade de Londrina, Paraná, foram comparados a este método padrão recomendado pela FAO os seguintes métodos: Radiação-Temperatura, Hicks-Hess, Hargreaves-Samani-1982,Turc, Priestley-Taylor, Tanner-pelton, Jensen-Haise,Makkink, HargreavesModificado, Stephens-Stewart, Abtew, Radiação-Global, Ivanov, Lungeon, Hargreaves-Samani-1985, Banavides-Lopez, Penman-Original, Linacre, Blaney-Morin, Romanenko, Hargreaves-1974, McCloud, Camargo, Hamon, Kharrufa, McGuiness-Bordne e Blaney-Criddle. Utilizando um conjunto de dados meteorológicos de aproximadamente 40 anos, as estimativas foram correlacionadas por regressão linear

1 Eng $^{\circ}$ Agr $^{\circ}$, M.e, Departamento de Agronomia, Centro de Ciências Agrárias, Universidade Estadual de Londrina, CCA/UEL, Londrina, PR, Brasil. E-mail: rodrigo.dlugosz@gmail.com

2 Prof. Drs., Departamento de Agronomia, CCA/UEL, Londrina, PR, Brasil. E-mail: aguiaresilva@uel.br; canteri@uel.br

3 Bióloga, M.e Departamento de Agronomia, CCA/UEL, Londrina, PR, Brasil. E-mail: juliandrarosisca@gmail.com

4 Eng $^{\circ}$ Agr $^{\circ}$, Discente de Mestrado em Agronomia, Departamento de Agronomia, CCA/UEL, Londrina, PR, Brasil. E-mail: nilsonvieirajunior@live.com

* Author for correspondence 
e avaliadas através do coeficiente de correlação de Person "r", índice de concordância "d" e do índice de desempenho "c". Os métodos Hargreaves Modificado, Stephens-Stewart, Abtew, Radiação-Global, Ivanov, Lungeon, Hargreaves-Samani-1985, Banvides-Lopez, Penman-Original e Linacre devem ser evitados, pois não apresentaram resultados ótimos. Classificado como "péssimo" os métodos McCloud, Camargo, Hamon, Kharrufa, McGuinness-Bordne, Blaney-Criddle, Hargreaves-1974, Romanenko e Blaney-Morin não são recomendados. E os métodos Radiação-Temperatura, Hicks-Hess, HargreavesSamani-1982, Turc, Priestley-Taylor, Tenner-Pelton, Jensen-Haise e Makkink apresentaram índices de desempenhos "ótimos", e podem ser aplicados para a região em estudo.

Palavras-chave: Evapotranspiração potencial. Modelos de cálculo. Tomada de decisão.

\section{Introduction}

Reference evapotranspiration (ETo) is a key component in estimating the amount of water required to maximize agricultural production. Defined by Allen et al. (1998) as the simultaneous process of plant transpiration and soil surface water evaporation over a period of time, the accuracy of its estimation is essential for water resources management, agricultural production forecasting, irrigation scheduling, and solving hydrological and meteorological problems (GOCIC; TRAJKOVIC, 2010).

Irrigation is responsible for about $70 \%$ of the global water consumption, so the precise estimation of ETo is the key parameter for the planning and management of irrigation systems, allowing to calculate the adequate amount of water to be replenished for the crop (WHO, 2013; CAVALCANTE JUNIOR et al., 2011). Rationalizing the use of water through the correct determination of crop evapotranspiration is essential to make agriculture sustainable and resilient.

Among the several methods of estimating ETo, the Penman-Monteith FAO56 method (ALLEN et al., 1998), parameterized by FAO, is recommended as a standard because it is more accurate in different regions of the world. However, this method requires a great deal of meteorological data such as air temperature, relative humidity, solar radiation balance, and wind speed, making its estimation possible only with a complete set of data, being limited to meteorological stations that monitor all these variables (FIETZ; FISCH,
2009; SENTELHAS et al., 2010). According to Conceição (2010), data acquisition and complexity of calculations make this method little used, leading to the search for simpler methods.

Several alternative methods are used to estimate ETo. However, these methods were developed under different climatic conditions of those in which it is applied (SENTELHAS et al., 2010). Therefore, it is of paramount importance to assess the performance of these methods for the new conditions, as performed by several authors in different regions (BERTI et al., 2014; SHIRI et al., 2014; NGONGONDO et al., 2012; TABARI et al., 2011).

The aim of this study was to test the performance of the ETo estimation models temperature radiation, Hicks-Hess, Hargreaves-Samani (1982), Turc, Priestley-Taylor, Tanner-Pelton, Jensen-Haise, Makkink, modified Hargreaves, Stephens-Stewart, Abtew, global radiation, Ivanov, Lungeon, Hargreaves-Samani (1985), BenavidesLopez, original Penman, Linacre, Blaney-Morin, Romanenko, Hargreaves (1974), McCloud, Camargo, Hamon, Kharrufa, McGuiness-Bordne, and Blaney-Criddle in relation to the standard method recommended by FAO, the PenmanMonteith FAO56, for Londrina, Paraná, Brazil.

\section{Material and Methods}

The study was carried out for the city of Londrina, Paraná, Brazil $\left(23^{\circ} 18^{\prime} 37^{\prime \prime} \mathrm{S}, 5^{\circ} 09^{\prime} 46^{\prime \prime} \mathrm{W}\right.$, and an altitude of $610 \mathrm{~m}$ ), with a climate type $\mathrm{Cfa}$ according 
to Köppen classification, i.e. a humid subtropical climate with average annual precipitation of 1626 mm (CARAMORI, 2009).

The Agronomic Institute of Paraná (IAPAR) and Meteorological System of Paraná (SIMEPAR) provided the meteorological data used in the study in a period of approximately 40 years (January 1, 1976 to April 30, 2016).

Twenty-seven alternative methods for estimating ETo (Table 1) were compared to the PenmanMonteith FAO56 method (ALLEN et al., 1998), which is a standard suggested by FAO.

Table 1. Methods used to estimate the reference evapotranspiration (ETo).

\begin{tabular}{ll}
\hline Method & Source \\
\hline Penman-Monteith FAO56 & (ALLEN et al.,1998) \\
Temperature radiation & (OUDIN et al., 2005) \\
Hicks-Hess & (BRUIN; KEIJMAN, 1979) \\
Hargreaves-Samani (1982) & (HARGREAVES; SAMANI, 1982) \\
Turc & (TURC, 1961) \\
Priestley-Taylor & (PRIESTLEY; TAYLOR, 1972) \\
Tanner-Pelton & (BERLATO; MOLION, 1981) \\
Jensen-Haise & (JENSEN; HAISE,1963) \\
Makkink & (MAKKINK, 1957) \\
Modified Hargreaves & (SENTELHAS; CAMARGO, 1996) \\
Stephens-Stewart & (WINTER et al., 1995) \\
Abtew & (OUDIN et al., 2005) \\
Global radiation & (TOMAR; O'TOOLE, 1980) \\
Ivanov & (DORFMAN, 1977) \\
Lungeon & (ZIMMERMANN, 2000) \\
Hargreaves-Samani (1985) & (HARGREAVES; SAMANI, 1985) \\
Benavides-Lopez & (GARCIA; LOPEZ, 1970) \\
Original Penman & (PENMAN, 1948) \\
Linacre & (LINACRE, 1977) \\
Blaney-Morin & (BLANEY; MORIN, 1942) \\
Romanenko & (OUDIN et al., 2005) \\
Hargreaves (1974) & (HARGREAVES, 1974) \\
McCloud & (JACOBS; SATTI, 2001) \\
Camargo & (CAMARGO, 1971) \\
Hamon & (HAMON, 1961) \\
Kharrufa & (KHARRUFA, 1985) \\
McGuiness-Bordne & (OUDIN et al., 2005) \\
Blaney-Criddle & \\
& \\
\hline & \\
&
\end{tabular}

Camargo and Sentelhas (1997) proposed a values and a standard. methodology to verify the performance of several evapotranspiration models, classifying them by means of the correlation between the estimated

For the correlation between models, we used the linear regression analysis and the following indicators: coefficient of determination $\left(\mathrm{R}^{2}\right)$; 
Pearson's correlation coefficient (r)(COHEN, 1988), calculated by Equation 1 (Figure 1), expressing the accuracy since it indicates the degree of dispersion of data in relation to the mean (random error); concordance or Willmott index (d) (WILLMOTT et al., 1985), calculated by Equation 2 (Figure 1), expressing the accuracy since it represents the distancing from the estimated values in relation to those observed; and confidence or performance index (c), suggested by Camargo and Sentelhas (1997) and calculated by Equation 3 (Figure 1). After the statistical assumptions are met, the data were analyzed by using the statistical program $\mathrm{R}(\mathrm{R}$ CORE TEAM, 2016).

Figure 1. Equations for calculating the concordance or Willmott index (d) (1), Pearson's correlation index (r) (2), and confidence or performance index (c) (3).

$$
d=1-\frac{\sum_{i=1}^{n}\left(Y_{i}-X_{i}\right)^{2}}{\sum_{i=1}^{n}\left[\left(\left|Y_{i}-\bar{X}\right|\right)+\left(\left|X_{i}-\bar{X}\right|\right)^{2}\right]^{2}} \quad r=\frac{\sum_{i=1}^{n}\left(\left|X_{i}-\bar{X}\right|\right)\left(\left|Y_{i}-\bar{Y}\right|\right)}{\sqrt{\sum_{i=1}^{n}\left(X_{i}-\bar{X}\right)^{2}} \sqrt{\sum_{i=1}^{n}\left(Y_{i}-\bar{Y}\right)^{2}}} \quad c=r d
$$

The obtained performance index (c) values were classified according to Table 2.

Table 2. Performance coefficient values according to Camargo and Sentelhas (1997).

\begin{tabular}{cc}
\hline c values & Performance \\
\hline$>0.85$ & Excellent \\
$0.76-0.85$ & Very good \\
$0.66-0.75$ & Good \\
$0.61-0.65$ & Satisfactory \\
$0.51-0.60$ & Poor \\
$0.41-0.50$ & Bad \\
$\leq 0.40$ & Very bad \\
\hline
\end{tabular}

\section{Results and Discussion}

Table 3 and Figure 2 show that the performance of eight of the 27 proposed methods was excellent: temperature radiation, Hicks-Hess, HargreavesSamani (1982), Turc, Priestley-Taylor, TennerPelton, Jensen-Haise, and Makkink. These methods achieved a performance index (c) higher than 0.85 , being classified as excellent. The other analyzed indices (Table 3) confirmed the excellent performance of these models, in which the precision (r), accuracy (d), and the coefficient of determination
$\left(\mathrm{R}^{2}\right)$ were very good, all of them above 0.90 . The accuracy of these methods can be attributed to the use of global radiation or radiation balance as input variables. Radiation balance is the main energy source available for the evapotranspiration process, being a function of the global radiation. Therefore, methods that use these variables characterize energetically and microclimatically the local, giving to the estimation a greater precision, which is in accordance with Ferreira et al. (2015), Reis et al. (2007), and Tagliaferre et al. (2010), who 
observed similar results. In general, methods that use these meteorological variables present good ETo estimations for any climatic condition.

The methods modified Hargreaves, StephensStewart, and Abtew were classified as very good, with a confidence index of $0.84,0.83$, and 0.80 , respectively, in accordance with Sentelhas and Camargo (1996) and Cunha et al. (2013), who found good estimations when using these methods. The methods Stephens-Stewart and Abtew, analogous to the excellent methods, use the global radiation, providing a greater credibility to the method. However, the method modified Hargreaves requires only temperature and relative air humidity data, making it an alternative in the absence of meteorological data to replace methods that require solar radiation as an input variable. Models that use a smaller number of variables have a greater potential for use due to their ease and information availability. However, these models should be used with caution, as they do not present good estimations for climatic conditions different from those for which they were developed (SENTELHAS et al., 2010).

Table 3. Coefficient of determination $\left(\mathrm{R}^{2}\right)$, correlation coefficient (r), concordance index (d), and performance index (c) resulting from the correlations between the proposed methods for estimating the reference evapotranspiration (ETo) and the standard Penman-Monteith FAO56, in Londrina, Paraná, Brazil.

\begin{tabular}{|c|c|c|c|c|c|}
\hline Method & $\mathbf{R}^{2}$ & $\mathbf{r}$ & d & c & Performance \\
\hline Temperature radiation & 0.92 & 0.96 & 0.98 & 0.94 & Excellent \\
\hline Hicks-Hess & 0.91 & 0.95 & 0.98 & 0.93 & Excellent \\
\hline Hargreaves-Samani (1982) & 0.90 & 0.95 & 0.97 & 0.93 & Excellent \\
\hline Turc & 0.92 & 0.96 & 0.96 & 0.93 & Excellent \\
\hline Priestley-Taylor & 0.90 & 0.95 & 0.97 & 0.92 & Excellent \\
\hline Tanner-Pelton & 0.91 & 0.95 & 0.93 & 0.89 & Excellent \\
\hline Jensen-Haise & 0.90 & 0.95 & 0.92 & 0.87 & Excellent \\
\hline Makkink & 0.90 & 0.95 & 0.90 & 0.86 & Excellent \\
\hline Modified Hargreaves & 0.82 & 0.91 & 0.92 & 0.84 & Very good \\
\hline Stephens-Stewart & 0.90 & 0.95 & 0.88 & 0.83 & Very good \\
\hline Abtew & 0.87 & 0.93 & 0.86 & 0.80 & Very good \\
\hline Global radiation & 0.87 & 0.93 & 0.78 & 0.73 & Good \\
\hline Ivanov & 0.67 & 0.82 & 0.86 & 0.70 & Good \\
\hline Lungeon & 0.68 & 0.83 & 0.85 & 0.70 & Good \\
\hline Hargreaves-Samani (1985) & 0.65 & 0.81 & 0.84 & 0.68 & Good \\
\hline Benavides-Lopez & 0.70 & 0.84 & 0.81 & 0.68 & Good \\
\hline Original Penman & 0.96 & 0.98 & 0.69 & 0.67 & Good \\
\hline Linacre & 0.71 & 0.84 & 0.78 & 0.66 & Good \\
\hline Blaney-Morin & 0.75 & 0.86 & 0.70 & 0.60 & Poor \\
\hline Romanenko & 0.68 & 0.82 & 0.69 & 0.57 & Bad \\
\hline Hargreaves (1974) & 0.65 & 0.81 & 0.57 & 0.46 & $\mathrm{Bad}$ \\
\hline McCloud & 0.31 & 0.55 & 0.72 & 0.40 & Very bad \\
\hline Camargo & 0.31 & 0.56 & 0.69 & 0.39 & Very bad \\
\hline Hamon & 0.32 & 0.57 & 0.67 & 0.38 & Very bad \\
\hline Kharrufa & 0.32 & 0.56 & 0.58 & 0.33 & Very bad \\
\hline McGuiness-Bordne & 0.30 & 0.55 & 0.57 & 0.31 & Very bad \\
\hline Blaney-Criddle & 0.32 & 0.57 & 0.55 & 0.31 & Very bad \\
\hline
\end{tabular}


Figure 2. Regression analysis between reference evapotranspiration estimated by Penman-Monteith FAO56 and other methods.

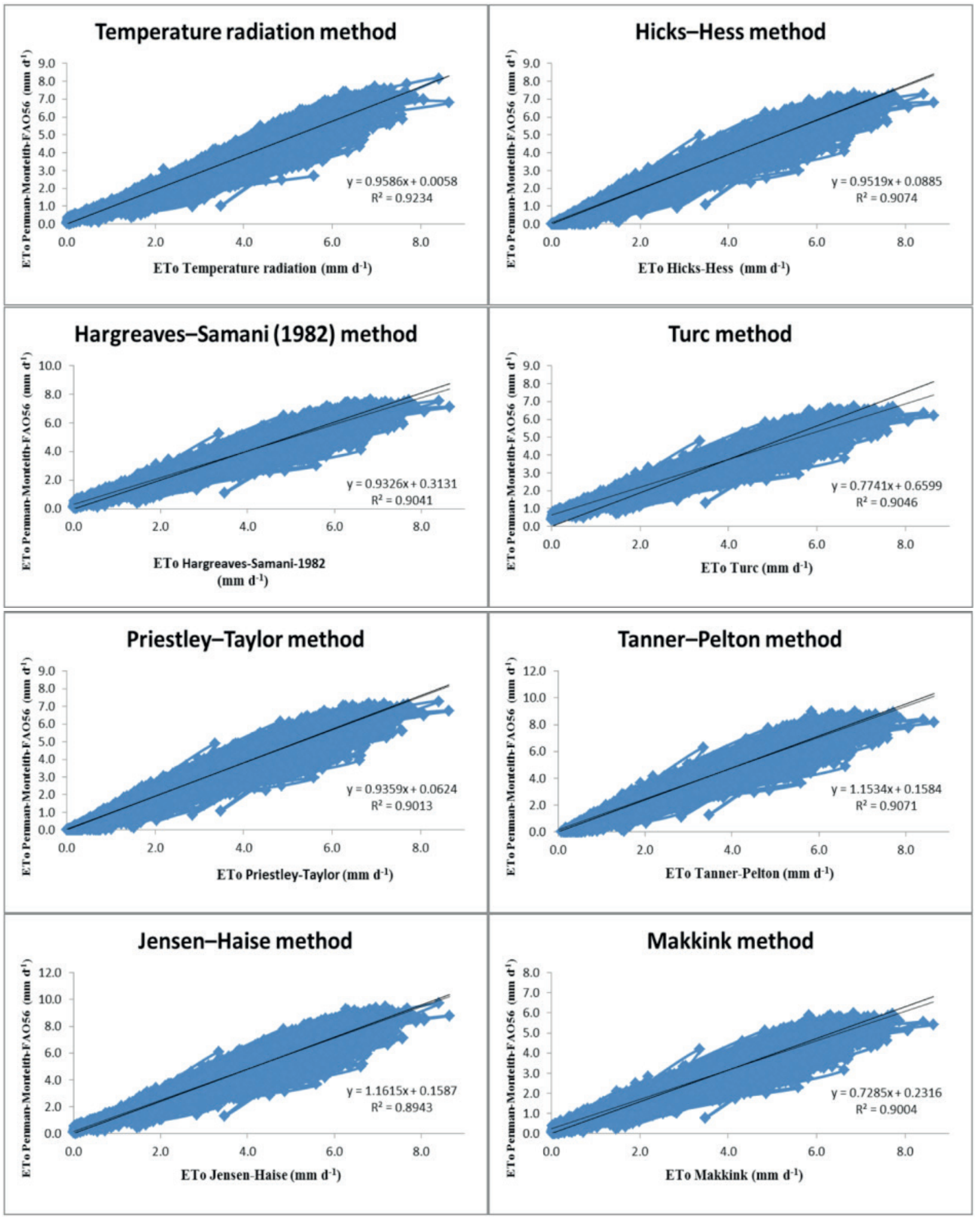




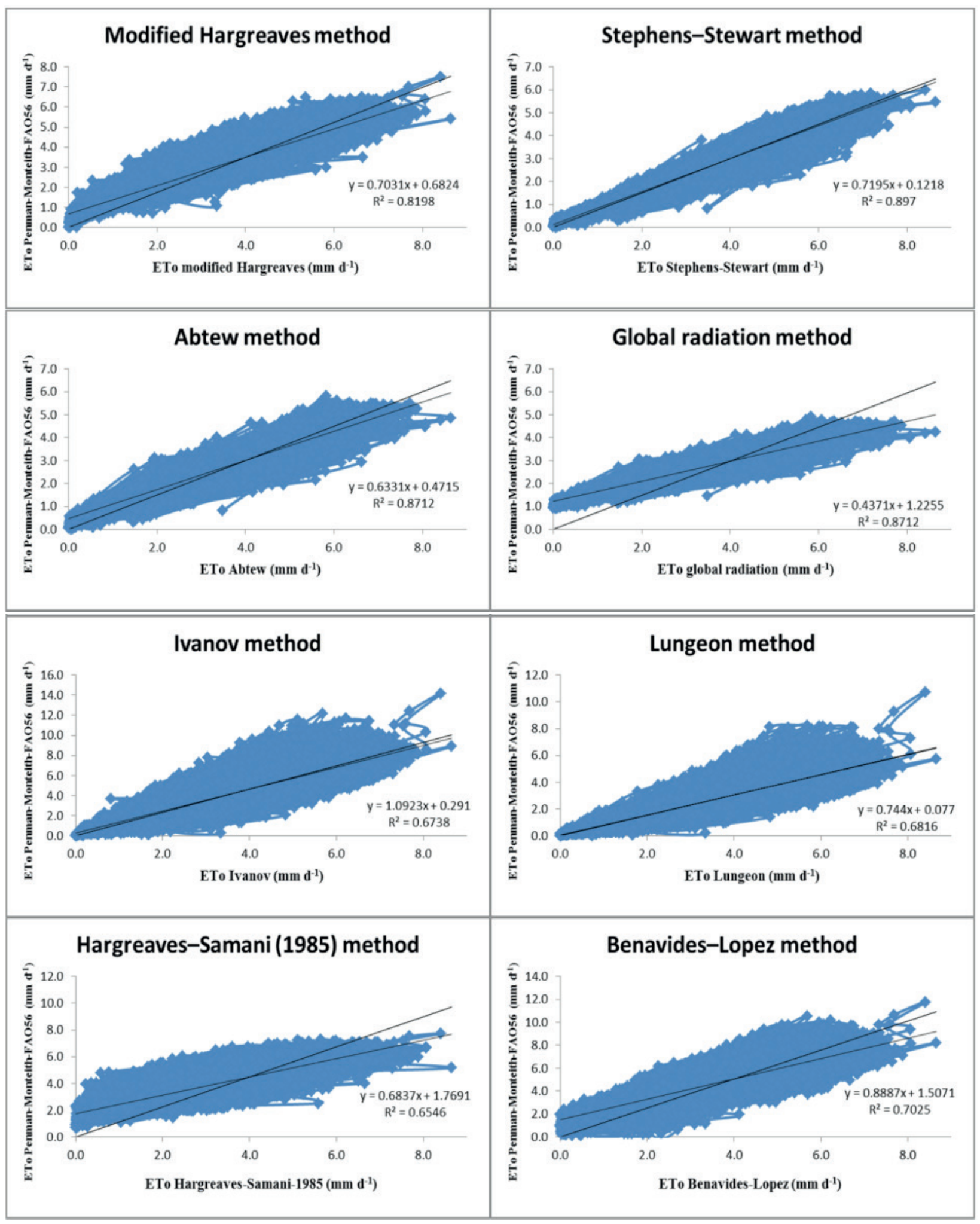




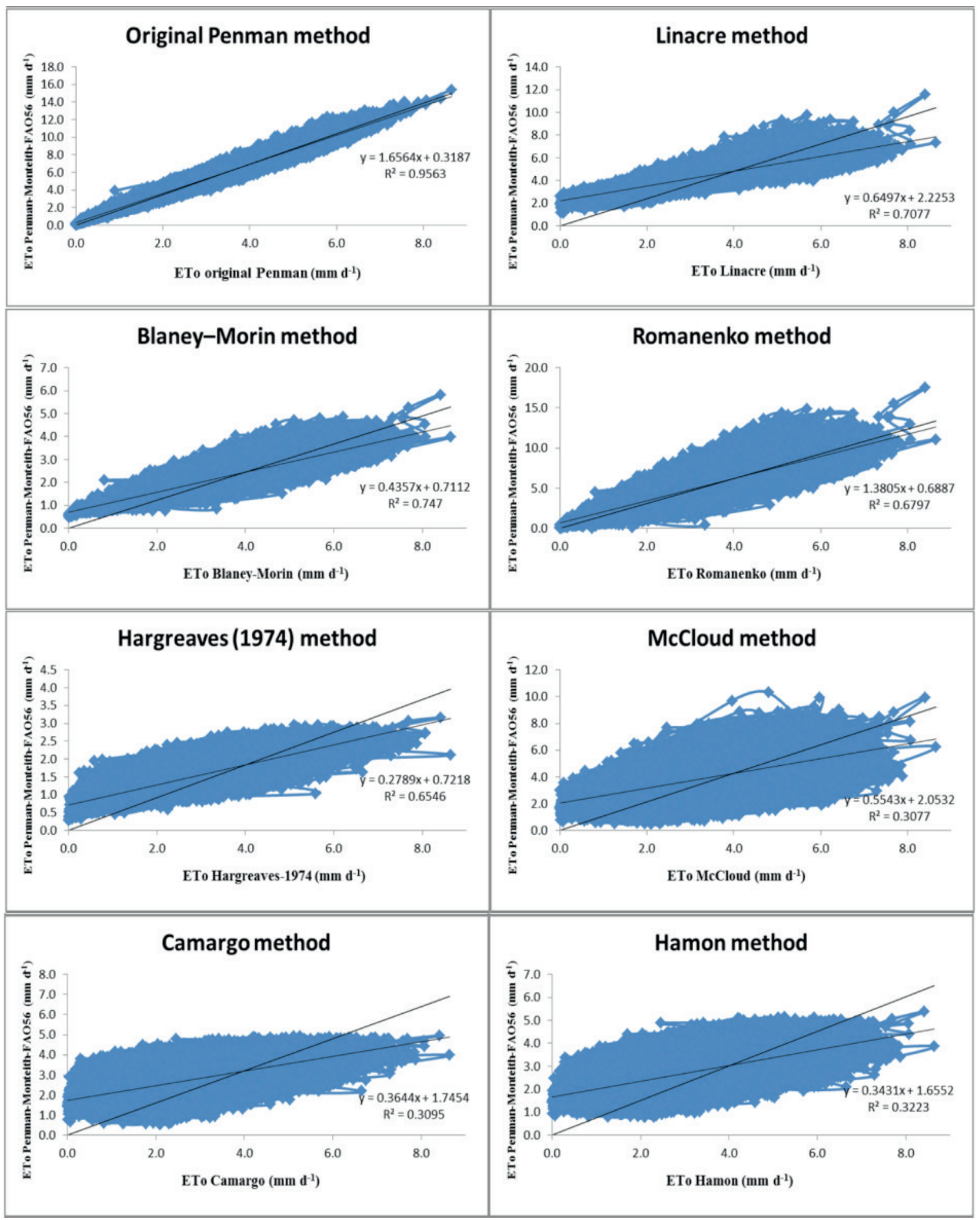




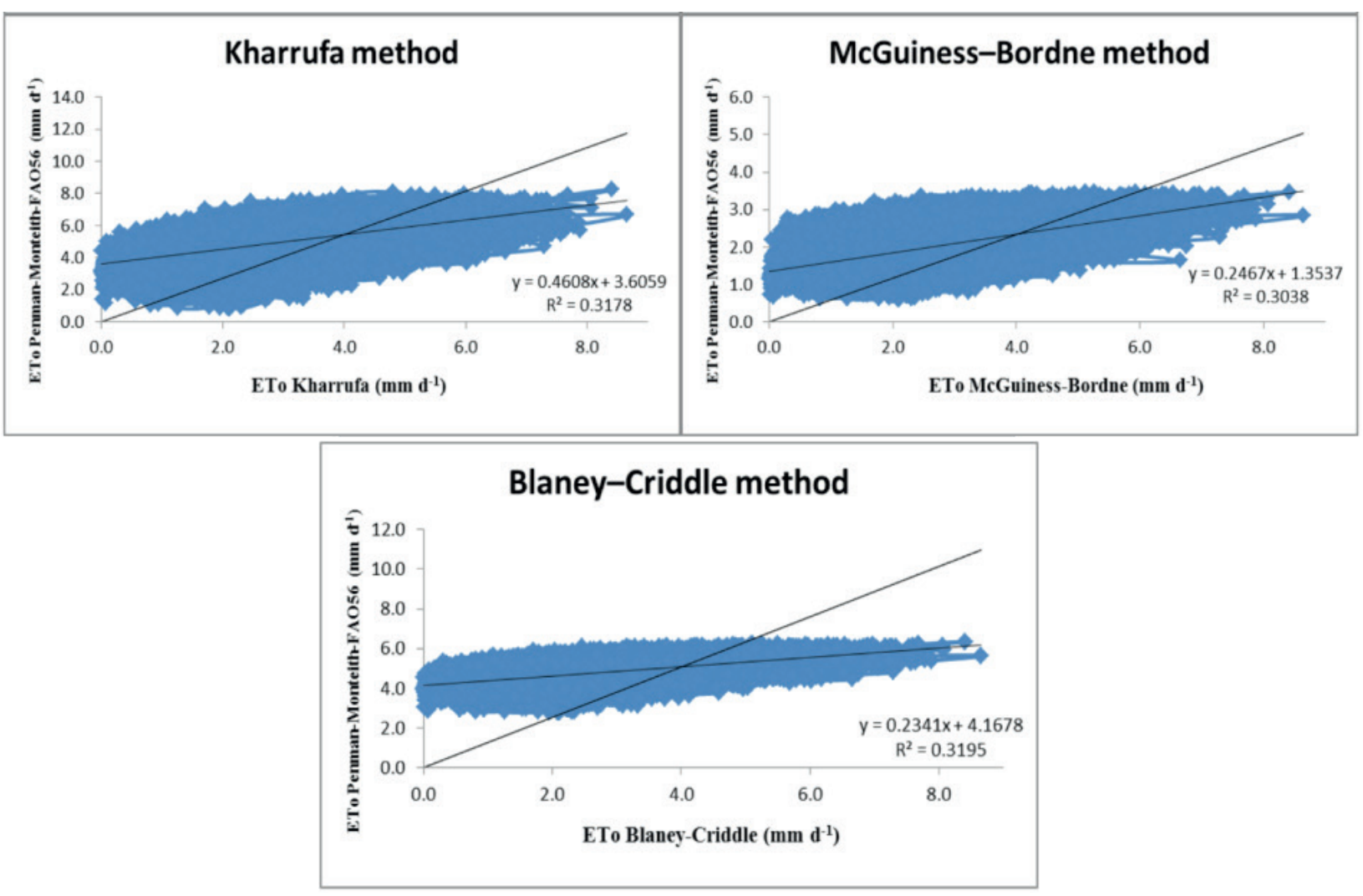

The methods Linacre, original Penman, Benavides-Lopez, Hargreaves-Samani (1985), Lungeon, Ivanov, and global radiation presented a good performance, with the $\mathrm{c}$ index varying from 0.66 to 0.73 . Figure 2 presents the distancing from the regression straight line to the straight-line $y$ $=\mathrm{x}$, showing a less accuracy of methods, with a low $\mathrm{R}^{2}$ for the Hargreaves-Samani (1985) method and a decrease of the Willmott index (d) for the original Penman method. The lower performance of the methods Hargreaves-Samani (1985), Linacre, Benavides-Lopez, Lungeon, and Ivanov when compared to other models was also observed by several authors in other regions (OLIVEIRA et al., 2008; ALENCAR et al., 2011; CUNHA et al., 2013), which can be attributed to the fact that these methods consider only data of temperature or temperature and relative air humidity, excluding the interference of other meteorological variables in evapotranspiration. However, the method Hargreaves-Samani (1985) presented reasonable precision and accuracy indices, being possible to propose, as in Sentelhas and Camargo (1996), a local calibration to the method so that producers in the region without access to complex meteorological data can manage the irrigation only with minimum, maximum, and average temperature data.

The method Blaney-Morin, with a performance index c equal to 0.60 , was classified as poor. Cunha et al. (2013), Peña and Peña (2010), and Ejieji (2011) found similar results. The methods Romanenko and Hargreaves (1974) were classified as bad, showing indices of 0.57 and 0.46 , respectively. These methods use few input variables. In the method Romanenko, the variables temperature and relative air humidity are obtained monthly, compromising its accuracy. The method Hargreaves (1974) uses as the measured input variable only air temperature, which alone does not represent the evapotranspirometric demands of the region, in addition to overestimating the ETo in humid climate regions. 
The models proposed by McCloud, Camargo, Hamon, Kharrufa, McGuinness-Bordne, and Blaney-Criddle showed the worst performance, presenting a confidence index (c) below 0.40 and being classified as very bad, the lowest performance level proposed by Camargo and Sentelhas (1997). All their indices were unsatisfactory (Table 3), with a great distancing of the regression straight line from the standard straight line (Figure 2). These methods use only air temperature as the measured variable, being the rest of variables tabulated, which may justify the low accuracy when compared to the reference method. According to Medeiros et al. (1998), methods that use only air temperature have a worse estimation of ETo. Other authors also observed the inefficiency of these models (BARROS et al., 2009; CAVALCANTE JUNIOR et al., 2011; TERRA et al., 2009; CUNHA et al., 2013).

\section{Conclusions}

Comparing the different estimation methods of ETo with the Penman-Monteith FAO56 for Londrina, Paraná, Brazil, we can conclude that:

The estimations were achieved by the methods temperature radiation, Hicks-Hess, HargreavesSamani (1982), Turc, Priestley-Taylor, TennerPelton, Jensen-Haise, and Makkink, which can be used as an alternative to the reference method.

The methods modified Hargreaves, StephensStewart, Abtew, global radiation, Ivanov, Lungeon, Hargreaves-Samani (1985), Benavides-Lopez, original Penman, and Linacre must be avoided or used with caution. In the absence of solar radiation data, the method modified Hargreaves is an alternative to the excellent methods.

The methods McCloud, Camargo, Hamon, Kharrufa, McGuinness-Bordne, Blaney-Criddle, Hargreaves (1974), Romanenko, and Blaney-Morin must not be used.

\section{References}

ALENCAR, L. P.; DELGADO, R. C.; ALMEIDA, T. S.; WANDERLEY, H. S. Comparação de diferentes métodos de estimativa diária da evapotranspiração de referência para a região de Uberaba. Revista Brasileira de Ciências Agrárias, Recife, v. 6, n. 2, p. 337-343, 2011.

ALLEN, R. G.; PEREIRA, L.; RAES, D.; SMITH, M. Crop evapotranspiration - guidelines for computing crop water requirements. Rome: FAO, 1998. 15 p. (FAO Irrigation and Drainage Paper, 56).

BARROS, V. R.; SOUZA, A. P.; FONSECA, D. C.; SILVA, L. B. D. Avaliação da evapotranspiração de referência na região de Seropédica, Rio de Janeiro, utilizando lisímetro de pesagem e modelos matemáticos. Revista Brasileira de Ciências Agrárias, Recife, v. 4, n. 2, p. 198-203, 2009.

BERLATO, M. A.; MOLION, L. C. B. Evaporação e evapotranspiração. Porto Alegre: IPAGRO/Secretaria de Agricultura, 1981. n. 7, 95 p. (Boletim técnico).

BERTI, A.; TARDIVO, G.; CHIAUDANI, A.; RECH, F.; BORIN, M. Assessing reference evapotranspiration by the Hargreaves method in north-eastern Italy. Agricultural Water Management, Amsterdam, v.1 40, n. 10, p. 20-25, 2014.

BLANEY, H. F.; CRIDDLE, W. O. Determining water requirements in irrigated area from climatological and irrigation data. Washington, USDA: [s.n.], 1950. 48 p. (Technical paper, 96).

BLANEY, H. F.; MORIN, K. V. Evaporation and consumptive use of water: empirical formulas. Transaction American Geophysical Union, Washington, v. 23, n. 1 , p. 76-83, 1942.

BRUIN, H. A. R.; KEIJMAN, J. Q. The Priestley-Taylor evaporation model applied to large, shallow lake in the Netherlands. Journal of Applied Meteorology, New York, v. 18, n. 7, p. 898-903, 1979.

CAMARGO, A. P. Balanço hídrico no estado de São Paulo. 3. ed. Campinas, IAC, 1971.24 p. (Boletim, n. 116).

CAMARGO, A. P. de; SENTElHAS, P. C. Avaliação do desempenho de diferentes métodos de estimativa da evapotranspiração potencial no estado de São Paulo. Revista Brasileira de Agrometeorologia, Santa Maria, v. 5, n. 1, p. 89-97, 1997.

CARAMORI, P. H.; GONÇALVES, S. L.; FARIA, R. T. F. Zoneamento agrícola do Estado do Paraná. Londrina: IAPAR, 2009. $76 \mathrm{p}$.

CAVALCANTE JUNIOR, E. G.; OLIVEIRA, A. D.; 
ALMEIDA, B. M.; ESPÍNOLA SOBRINHO, J. Métodos de estimativa da evapotranspiração de referência para as condições do semiárido Nordestino. Semina: Ciências Agrárias, Londrina, v. 32, p. 1699-1708, 2011. Suplemento.

CONCEIÇÃO, M. A. F. Evapotranspiração de referência com base na radiação solar global estimada pelo método de Bristow-Campbell. Engenharia Agrícola, Jaboticabal, v. 30, n. 4, p. 619-626, 2010.

COHEN, J. Statistical power analysis for the behavioral sciences. New Jersey: Lawrence Erlbaum, 1988. 569 p.

CUNHA, F. F.; MAGALHÃES, F. F.; CASTRO, M. A. Métodos para estimativa da evapotranspiração de referência para Chapadão do Sul - MS. Engenharia na Agricultura, Viçosa, v. 21, n. 2, p. 159-172, 2013.

DORFMAN, R. Critérios de avaliação de alguns métodos de cálculo da evapotranspiração potencial. 1977. Dissertação (Mestrado em Ciência Espacial e da Atmosfera) - Universidade Federal do Rio Grande do Sul, Porto Alegre.

EJIEJI, C. J. Performance of three empirical reference evapotranspiration models under three sky conditions using two solar radiation estimation methods at Ilorin, Nigeria. Agricultural Engineering International, Beijing, v. 13, n. 3, p. 1-21, 2011.

FERREIRA, P. F.; ALLASIA, D. G.; CECONI, D. E.; FONTOURA, J. R.; BASSO, R. E. Análise comparativa dos métodos de estimativa da taxa de evapotranspiração de referência para a região sul do brasil. In: SIMPÓSIO BRASILEIRO DE RECURSOS HÍDRICOS, SBRH, 21., 2015, Brasília. Anais... Porto Alegre: ABRH, 2015.

FIETZ, C. R.; FISCH, G. F. Avaliação de modelos de estimativa do saldo de radiação e do método de PriestleyTaylor para a região de Dourados, MS. Revista Brasileira Engenharia Agrícola Ambiental, Campina Grande, v. 13, n. 4, p. 449-453, 2009.

GARCIA, B. J.; LOPEZ, D. Formula para el caçulo de laevapotranspiracion potencial adaptada al tropico $\left(15^{\circ}\right.$ $\mathrm{N}-15^{\circ}$ S). Agronomia Tropical, Maracay, v. 20, n. 5, p. 335-345, 1970.

GOCIC, M.; TRAJKOVIC, S. Software for estimating reference evapotranspiration using limited weather data. Computers and Electronics in Agriculture, New York, v. 71, n. 2, p. 158-162, 2010.

HAMON, W. R. Estimating potential evapotranspiration. Journal of Hydraulics Division ASCE, New York, v. 87, n. 3, p. 107-120, 1961.

HARGREAVES, G. H. Estimation of potential and crop evapotranspiration. Transactions of the ASAE, St. Joseph, v. 17, n. 4, p. 701-704, 1974.

HARGREAVES, G. H.; SAMANI, Z. A. Estimating potential evapotranspiration. Journal of the Irrigation and Drainage Division of the ASCE, New York, v. 108, n. IR3, p. 223-230, 1982.

HARGREAVES, G. L.; SAMANI, Z. A. Reference crop evapotranspiration from temperature. Journal of the Irrigation and Drainage Division ASCE, New York, v. 111, n. 1, p. 113-124, 1985.

JACOBS, J. M.; SATTI, S. R. Evaluation of reference evapotranspiration methodologies and AFSIRS crop water use simulation model. Gainesville: Department of Civiland Coast al Engineering, University of Florida, 2001. 114 p. (Final Report).

JENSEN, M. E.; HAISE, H. R. Estimating evapotranspiration from solar radiation. Journal of the Irrigation and Drainage Division ASCE, New York, v. 4, n. 1, p. 15-41, 1963.

KHARRUFA, N. S. Simplified equation for evapotranspiration in arid regions. Beiträgezur Hydrologie: Sonderheft, Kirchzarten, v. 5, n. 1, p. 39-47, 1985.

LINACRE, E. T. A simple formula for estimating evaporation rates in various climates, using temperature data alone. Agricultural Meteorology, Amsterdam, v. 18, n. 6, p. 409-424, 1977.

MAKKINK, G. F. Ekzamento de la formulo de Penman. Netherlands Journal of Agricultural Science, Wageningen, v. 5, n. 3, p. 290-305, 1957.

MEDEIROS, S. L. P.; MANFRONI, P. A.; BIANCHI, C. Avaliação de métodos de estimativa da evapotranspiração de referência para região mesoclimática de Santa MariaRS. Revista Brasileira de Agrometeorologia, Santa Maria, v. 6, n. 1, p. 105-109, 1998.

NGONGONDO, C.; YU XU, C.; TALLAKSEN, L. M.; ALEMAW, B. Evaluation of the FAO PenmanMontheith, Priestley-Taylor and Hargreaves models for estimating reference evapotranspiration in southern Malawi. Hydrology Research, London, v. 44, n. 4, p. 706722, 2012.

OLIVEIRA, R. A.; TAGLIAFERRE, C.; SEDIYAMA, G. C.; MATERAM, F. J. V.; CECON, P. R. Desempenho do Irrigâmetro na estimativa da evapotranspiração de referência. Revista Brasileira de Engenharia Agrícola e Ambiental, Campina Grande, v. 12, n. 2, p. 166-173, 2008.

OUDIN, L.; MICHEL, C.; ANCTIL, F. Which potential evapotranspiration input for a lumped rainfall-runoff model: part 1-can rainfall- runoff models effectively 
handle detailed potential evapotranspiration inputs. Journal of Hydrology, Amsterdam, v. 303, n. 1-4, p. $290-$ 306, 2005.

PENMAN, H. L. Natural evaporation from open water, bare soil and grass. Proceedings of the Royal Society. Mathematical and Physical Sciences, London, v. 193, n. 3, p. 120-145, 1948.

PEÑA, L. S.; PEÑA, E. P. Obtención de modelos para la determinación de la evapotranspiración de referencia en condiciones de clima subhúmedo seco en las tunas, cuba. Idesia, Arica, v. 28, n. 1, p. 55-59, 2010.

PRIESTLEY, C. H. B.; TAYLOR, R. J. On the assessment of surface heat flux and evaporation using large-scale parameters. Monthly Weather Review, Boston, v. 100, n. 2, p. 81-92, 1972.

R CORE TEAM - R. A language and environment for statistical computing. R Foundation for Statistical Computing. Vienna: Austria, 2016. Available at: $<$ https:// www.R-project.org/>. Accessed at: 22 fev. 2017.

REIS, E. F.; BRAGANÇA, R.; GARCIA, G. O. Estudo comparativo da estimativa da evapotranspiração de referência para três localidades do Estado do Espírito Santo no período seco. Idesia, Arica, v. 25, n. 3, p. 7578, 2007.

SENTELHAS, P. C.; CAMARGO, A. P. D. E. Equação para a estimativa da evapotranspiração potencial no estado de São Paulo, baseada no método de Hargreaves 1974. Revista de Agrometeorologia, Santa Maria, v. 4, n. 1, p. 77-81, 1996.

SENTELHAS, P. C.; GILLESPIE, T. J.; SANTOS, E. A. Evaluation of FAO Penman-Monteith and alternative methods for estimating reference evapotranspiration with missing data in Southern Ontario, Canada. Agricultural Water Management, Amsterdam, v. 97, n. 5, p. 635-644, 2010.

SHIRI, J.; NAZEMI, A. H.; SADRADDINI, A. A.; LANDERAS, G.; KISI, O.; FARD, A. F.; MARTI, P. Comparison of heuristic and empirical approaches for estimating reference evapotranspiration from limited inputs in Iran. Computers and Electronics in Agriculture, Amsterdam, v. 28, n. 3, p. 1215-1225, 2014.

TABARI, H.; MAROFI, S. Changes of pan evaporation in the west of Iran. Water Resource Management, Netherlands, v. 25, n. 1, p. 97-111, 2011.
TAGLIAFERRE, C.; SILVA, R.; ROCHA, F.; SANTOS, L. Estudo comparativo de diferentes metodologias para determinação da evapotranspiração de referência em Eunápolis - BA. Revista Caatinga, Mossoró, v. 23, n. 1. p. 103-111, 2010.

TERRA, V. S. S.; TEIXEIRA, C. F. A.; REISSER JÚNIOR, C.; MADALOZ, L. M.; STEINMETZ, S.; ALMEIDA, I. R. de; TIMM, L. C. Evapotranspiração de referência por diferentes métodos para a região de Pelotas/RS. In: CONGRESSO DE INICIAÇÃO CIENTÍFICA, ENCONTRO DE PÓS-GRADUAÇÃO, MOSTRA CIENTÍFICA, 18., 11., 1.; 2009, Pelotas. Anais... Pelotas: Universidade Federal de Pelotas, 2009. CD-ROM.

TOMAR, V. S.; O'TOOLE, J. C. Water use in lowland rice cultivation in Asia: a review of evapotranspiration. Agricultural Water Management, New York, v. 3, n. 1, p. 83-106, 1980.

TURC, L. Evaluation des besoinsen eau d'irrigation, évapotranspiration potentielle, formule simplifié e et mise à jour. Annals of Agronomy, Paris, v. 12, n. 1, p. 13-49, 1961.

WILLMOTT, C. J.; CKLESON, S. G.; DAVIS, R. E. Statistics for the evaluation and comparision of models. Journal of Geophysical Research, Ottawa, v. 90, n. C5, p. 8995-9005, 1985.

WINTER, T. C.; ROSENBERRY, D. O.; STURROCK, A. M. Evaluation of 11 equations for determining evapotranspiration for a small lake in the north central United States. Water Resources Research, Colorado, v. 31, n. 4, p. 983-993, 1995.

WORLD HEALTH ORGAZINATION - WHO. Water Security \& the Global Water. Agenda AUN-Water Analytical Brief. Ontario: [s.n.], 2013. (Report of a WHO meeting of experts). Available at: $<$ http://www.unwater. org/downloads/watersecurity_analyticalbrief.pdf $>$. Accessed at: 22 fev. 2017. Londrina, Pr.

ZIMMERMANN, E. D. Evaporación, transpiración y evapotranspiraciónen Orsolini. In: ZIMMERMANN, E. D.; BASILE, P. A. (Ed.). Hidrologia: procesos y métodos. Rosario: UNR Editora, 2000. p. 65-89. 